\title{
The Impact of North American Free Trade Agreement on Women in the United States, Canada, and Mexico
}

\author{
Prescott C. Ensign
}

The North American Free Trade Agreement (NAFTA) will prove consequential in the years ahead. Some of the effects will be tremendous and others subtle. Many of the repercussions will be unique for women. Society shapes public policy, and in pursuit of national interests, public policy can take into consideration or neglect the individual. It has been cautioned that shortterm, narrowly focused views leave many individuals unaccounted for; there exists a great danger in making generalizations, particularly when individuals and their lives are at stake. To ensure prosperity for all, all must be considered.

\section{INTRODUCTION}

In the rush to obtain passage of the North American Free Trade Agreement (NAFTA), negotiators failed to address a number of important issues. Economic issues and predictions vastly overshadowed the impact NAFTA might have on human lives and in particular the lives of women. Women in the workforce as well as those with a working spouse may find their lives changed dramatically. In many cases the impact on women may be very significant, especially for those at the lower end of the wage scale.

NAFTA has the potential to influence women directly (their own job) or indirectly (the job of a spouse). Such employment statistics can often be quantified and easily measured (e.g., in overall terms, the number of jobs

Ensign, P.C. (2003) The Impact of the North American Free Trade Agreement on the Women of the United States, Canada, and Mexico. International Journal of Commerce \& Management. 13(2): 1-28. doi: 10.1108/eb047464 
gained may roughly equal the number of jobs lost). But the impact of NAFTA will also affect people's lives in a number of other ways. Positive or negative changes in economic condition, for example, can affect a person's physical health and well-being. In the event of negative changes in economic condition, the effect can be quite severe. Most of these consequences will probably never be measured statistically.

For the majority of women in the United States and Canada, NAFTA may not provide any real economic opportunity. Growth in income has already been declining. The average wage of women is below that of men. Women occupy a large percentage of all temporary and part-time positions that are characterized by low pay, few benefits, and little job security. A number of women in the U.S. have already lost jobs as plants have relocated to Mexico (or the U.S. for women in Canada). If there is a further downward pressure on wages or a reduction in number of jobs, the impact of NAFTA will have serious consequences for many women.

In the case of Mexico, it is doubtful that women will see any significant improvement in either wages or workplace conditions. Mexican women already work long hours for low wages. ${ }^{1}$ At one point, changes in economic policies in the 1980s decreased the purchasing power of their wages by as much as 60 percent. With a decline in farm income, many women have been forced to seek extra work. This trend is likely to continue. Although there may be tremendous benefits of failing prices on consumers generally, NAFTA may increase the burden for women, especially those already struggling to survive.

An examination into the nature of economic institutions and how they have an impact on our social and political fabric has been a continuously running theme among academic scholars, political leaders, and managers of business institutions, notably large corporations. It is necessarily so because as national economies become large, and economic systems become integrated, economic concerns tend to overwhelm other institutions of society. (Sethi, 1995: 18)

${ }^{1}$ According to the U.S. Commerce Department, low wages are defined as being less than 25 percent of U.S. wages. 


\section{INSTITUTIONAL UPHEAVAL}

\section{Governance/Control}

The formal integration of the three North American economies is yet to be tested. Propaganda-like prose abounds; an optimistic Canadian assessment provided an idyllic quote by John Kenneth Galbraith: "I was brought up to believe that the trade-and-immigration controls on the border were an unnatural abrasion of the rights of man - and woman. They should be kept at a minimum or not exist. It is a feeling I have never escaped" (Canada, 1993: 96). NAFTA provides multinational corporations (MNCs) with many benefits but few responsibilities. NAFTA does not hold these MNCs responsible for any disruption that they may cause in communities or individual lives. Even if one clings to Friedman's (1970) view that the social responsibility of business is solely profit seeking activity within the bounds of the law, it is clear that the times have changed. One can no longer hold the assumption that the corporation is ultimately accountable to the government. In fact the opposite may be true-as governmental laws are found to be a violation of free trade. For example, the General Agreement on Tariffs and Trade and now the new World Trade Organization enable MNCs to supersede and even overturn national laws (Alt-WID, 1995). Vernon (1994a: 1246) states that "the 1980s marked the end of an era, many decades in duration, in which governments around the world had been seen as relatively effective leaders in the development of their respective national economics." Vernon (1994a) finds that authoritarian regimes, even in industrialized countries, are no longer able to selectively screen the activities of the MNC. Hirst and Thompson (1992: 360) similarly note the "rise and maturity of the MNC"; the present paper builds on this issue and explicitly acknowledges that demarcation of a home base is difficult and that effective policing of MNC current activity and future endeavors is an arduous task.

\section{Social Structures}

Industrialization produces change in social structures; that is, MNCs intensify pressures for changes in society (Kobrin, 1975). Friedman (1962) refutes the belief that individual freedom is a political concern and that material welfare is an economic concern. Friedman (1962) unravels the relationship between economic freedom and political freedom. He finds the correlation 
between a free market and personal freedom to be strong and notes that the connection between the two is neither simple nor a unilateral relation. Friedman (1972) points to an invisible hand in politics operating contrary to the invisible hand in the market. Though insightful, his analysis falls short of the current condition where the force of free enterprise, particularly MNCs, holds the upper hand and can dictate political action. While returning to the days of the 'Robber Barons' is perhaps unimaginable, Johnson (1970) as well as Leftwich and Sharp (1980) iterate that large corporations are not easily kept in check. Boddewyn (1988) similarly notes how adeptly MNCs behave, performing political skills of access and influence and even exhibiting 'political intelligence.'

\section{Political Mechanisms}

Alternatively, as is increasingly the case, government may be responsive to the interests of transnational capital (Sklair, 1991). The Government of Canada (1992) recognizes that "today, the competition is over domestic policies that attract both domestic and international investors." Kobrin's (1976: 499) research demonstrates that foreign direct investment serves as a "vehicle for the cross-cultural transfer of values, attitudes, and institutions." Adam Smith's (1776) laissez faire doctrine, clearly value laden, allows competitive free market forces to serve as the mechanism whereby all consequences, both positive and negative, would be allocated. This classical free enterprise system is self-adjusting without government. In this Darwinian struggle for survival there is no guarantee that the result will be anything resembling what a fair and just society might deem conscionable. A refined view holds that income distribution is primarily the result of government action, whereas per capita income is primarily the result of transnational forces (Sklair, 1991). With respect to deciding on investment abroad or at home, differences in the criteria of the individual and society exist, thus leading to "possible conflict between the individual and the social optimum" (Jasay, 1960: 105). Banner (1979) calls for an assessment whereby social indicators are used to measure actual performance of society against an ideal. Longitudinal examination of factors contributing to social welfare would give greater insight into the impact of business on society. Joekes (1987: 10) states that "time lags intensify the information imbalance." For improved understanding, she points to the need for viewing economic changes over time 
with an emphasis on a search for trends and patterns.

For a certain percentage of persons to serve other persons in order that the ones so served may produce more, is a contribution not to be overlooked. The labour of women ... certainly enables men to produce more wealth than they otherwise could; and in this way women are economic factors in society. But so are horses. The labour of horses enables men to produce more wealth than they otherwise could. The horse is an economic factor in society. But the horse is not economically independent, nor is the woman. (Charlotte Perkins Gilman, 1898)

\section{Prospects for the Future}

Unlike the European Community, which instituted a social charter as part of its unification, no formal provisions have been made by Canada, Mexico, and the U.S. to assist those affected in the transition to a freer market economy. With high unemployment and budget deficits in Canada and the U.S., funds may not be adequate to assist in this transition. In the years ahead, many in the U.S., Canada, and Mexico may come to the conclusion proposed here: the combination of NAFTA and women provides few winners, with many women experiencing adverse affects.

\section{NAFTA AND WOMEN: THE UNITED STATES}

\section{NAFTA and US Wages}

While many believe that NAFTA will yield net economic gains for the U.S., these are most likely to come as increased profits for MNCs rather than as increased wages for individuals (Faux, 1993). For the individual, gains are not likely to be evident for most wage earners. The U.S. International Trade Commission (1991) finds that real income for unskilled workers is likely to decline 'slightly' and defines 'unskilled' workers as all those with a high-school education or less (approximately 70 percent of the labor force). Krugman (1993) also indicates a fall in the real wages of unskilled U.S. workers. It is possible that gains will accrue to those at the upper end of the income/wage scale. This would include persons with business ownership rights who can 
share directly in any profits that result from NAFTA. It might also include those in upper management positions with a salary and/or bonus tied directly to higher profits or those who receive a salary increase because the firm that employs them experiences increased profitability. Orme (1993) identifies negative effects (both economic and psychological) of NAFTA accruing to those in industries characterized as smaller, labor-intensive manufacturing, and having little international experience. Blau and Kahn (1992) note that despite the long commitment in the U.S. to policies of equal pay and equal employment opportunities, the U.S. gender pay differential is above average for the sample of developed countries they surveyed. The rationale provided is that "the U.S. labor market places a much larger penalty on those with lower levels of labor-market skills (both measured and unmeasured)" (Blau and Kahn, 1992: 534).

\section{U.S. Women and Wages}

Some persons may gain from NAFTA. Women, however, do not comprise a significant portion of this group. The number of women in top management positions in U.S. corporations is relatively small. Patterns of direct ownership are similar. Of those in the high wage group, therefore, men are more likely to experience gains. So what does this leave for women? If a large number of women are to benefit from NAFTA, gains would have to be made by those in the low and middle wage groups. During NAFTA negotiations, much attention was focused on these groups. Concerns were centered on the plight of low and middle-income jobs, resulting in a multitude of controversial debates. Labor unions and many others were actively involved. In most debates, however, very little attention was overtly given to the impact NAFTA will have on women. ${ }^{2}$

\section{U.S. Women and Displacement}

A number of studies have examined the overall displacement and unemployment patterns of persons in low and middle wage groups. And though it is "perhaps common knowledge that the gender composition of the workforce varies widely from industry to industry, this fact is often completely ignored in trade studies" (Short, Highfill, and Weber, 1994: 512). Historical

${ }^{2}$ For exceptions see Cohen (1987) and Macmillan (1988). 
evidence indicates that job losses occur most frequently in industries where wages are low (Joekes, 1987). Since women tend to occupy many of these jobs, the number of women that may be displaced would be quite significant. In industries where women represent a higher percentage of the workforce they will be affected disproportionately. Such industries include apparel, leather, textiles, food processing, and some sectors of the automotive and electronics industries. Eighty percent of workers in apparel are women. Many of these jobs are in large cities (e.g., New York and Los Angeles) and rural areas. Apparel workers in cities are often recent immigrants with few job alternatives and limited financial resources. Those in rural areas have limited mobility. If jobs disappear there may be no alternatives for employment. Statistically, women in these groups are displaced at more than twice the rate of men. The Congressional Budget Office finds that "women workers who are displaced tend to experience longer spells of joblessness than male workers (by 3.4 weeks) and to take deeper pay cuts when they are reemployed" (Lee, 1993: 2). In fact, Loprest (1992) finds that on average, young women have less than half the wage growth of young men when changing jobs. Bednarzik (1994) concludes that, with the exception of youth, in times of trade liberalization those most likely to lose their jobs will have the most difficulty relocating.

\section{U.S. Women and Industries}

Short, Highfill, and Weber (1994) find that those industries with a concentration of women are negatively related to net exports. The converse holds too; coal mining, with the lowest proportion of women ( 6 percent) in its labor force, has the highest net exports among the 24 SIC 2-digit manufacturing industries. Short, Highfill, and Weber (1994: 517) point out that high wage jobs are positively correlated with level of export and that "such industries are precisely those that are not likely to have women-intensive workforces." In an analysis of industries sensitive to foreign trade, Bednarzik (1993: 24) finds a greater concentration of women in import-sensitive industries than in export-sensitive industries and confirms that "job losses for women were concentrated in low-earnings, import-sensitive industries."

\section{U.S. Women and Race}

With the downward pressure on wage rates, some women will be forced to work at lower wages. The overall effect will likely be an increase in the 
already growing inequality of incomes in the United States. The impact realized may be greatest on female minority workers. Lee reports (1993:1): “our analysis shows that overall, African American, Hispanic, and Asian Americans hold a disproportionate share of the production jobs likely to be displaced by NAFTA ... Up to five years after displacement, African American and Hispanic workers are more likely to be unemployed than white workers." Displaced non-white workers are out of work an average of four weeks longer than are comparable white workers (Lee, 1993). Women in these minority groups may experience a very substantial loss.

\section{Prospects for the Future of Women in the US}

Many of the same workers already devastated by plant closings or wage cuts may also be affected by NAFTA. In the event of dislocation, they have no national health insurance, inadequate unemployment benefits, limited training or job search assistance, and no public jobcreation program. The level of help from the Trade Adjustment Assistance program has declined during the 1980s and will presumably be unable to meet the majority of needs. Overall, the proportion of U.S. GDP devoted to all public labor market programs is less than one-third of that in Canada (0.6 percent of GDP in the U.S. vs. 2.0 percent of GDP in Canada), and one-fourth of that in Western Europe (2.5 percent of GDP) (Friedman, 1992: 30).

Throughout NAFTA negotiations, most of the attention focused on the number of jobs that would be lost. President Clinton as well as members of Congress admitted that some number of jobs would be lost. Although job loss is vitally important, the debate could have gone beyond this issue. Attention might have focused on what happens to people once they lose their jobs and how they would receive assistance. At the congressional level, it could have resulted in national policies or programs, which might adequately address people's needs.

\section{NAFTA AND WOMEN: CANADA}

\section{Canadian Sovereignty-Economic and Political}

Of the three countries involved in NAFTA, Canada seems to be at the greatest disadvantage. There exists concern for Canada's economic vitality and its position to compete globally (Porter, 1991). As an economic 
community, Canada has been dominated by the U.S. throughout its history (Herremans, Ryans, and Rau, 1993). Clarkson (1988) recounts the considerable public arousal at the concentration of corporate power that ultimately resulted in a Royal Commission inquiry. A large proportion of MNCs are U.S.-based. The U.S. supplies nearly 80 percent of all foreign direct investment; the total nearly doubled from 1976-1985 (C\$32 billion to C $\$ 63$ billion) (Rugman, 1987: 48). Intrafirm trade accounts for a high percentage of all trade and can be expected to increase with NAFTA.

Canada is also at a disadvantage because it has a small economy compared to that of the United States. As a result, any shifts in production facilities or changes in the workforce will have a greater impact in Canada. Finally, Canada is at a disadvantage because the U.S. is the largest partner in NAFTA and based on the way NAFTA is written, the United States has the potential to wield a disproportionate share of influence. This will not be in Canada's favor. Extraterritoriality has become an increasing concern in the age of a borderless world (Ohmae, 1995). Eden and Molot (1993a) portray the MNCs functioning in a political economy in which global borders are falling as a modern day version of Sovereignty at Bay (Vernon, 1971). Kobrin (1976: 516) envisions "agreements allowing the participation of foreign enterprise [which] should provide for both a net positive contribution to indigenously determined development goals and a reasonable return to the investor."

\section{Canadian Women and NAFTA}

The impact of NAFTA on women in Canada can be expected to be similar to that for U.S. women. The pattern and the changes described for U.S. women can be expected for Canadian women too. Economic integration and free trade have increased emphasis on producing goods at the lowest cost. In order to compete in this environment, Canadian firms, both domestic and foreign owned, may demand that cost reductions come from the employees. For some firms the solution may be to relocate part or all of their production to take advantage of lower factor costs (wages, tax rates, etc.). With the threat of job loss, employees may be expected to produce more (at their current wage rate) or take a cut in pay to save their jobs. Since many women work for U.S.-based MNCs, they may not be able to count on a firm's primary loyalty to Canada or its workforce. To illustrate the tenuous relationship between globalization and social concern, consider what has happened to many women 
fish processors in Canada (two out of three fish processors are women) during the aftermath of the Canada-U.S. Free Trade Agreement. Unionized women fish processors, protected by pay equity laws, earning \$13 per hour watched as their jobs shifted to the U.S. where workers earned $\$ 5.50$ per hour with no pay equity protection (Alt-WID, 1993).

\section{Prospects from Past Experience in Canada}

A primary concern of women in Canada centers on the potential elimination of jobs and the downward pressure on wages. Since the Canada-U.S. Free Trade Agreement took effect in 1989, Canada has already seen a dramatic change in its economy. Between June 1989 and March 1992, there was a net loss of 511,000 jobs in the manufacturing sector. This represents a loss of 26 percent of the manufacturing jobs in Canada. By comparison, the U.S. experienced a 5.7 percent loss during this same period (Campbell, 1993: 100-101).

During this same period (1989-1992), there were productivity gains as would be expected. But the unit labor costs in manufacturing went up just as dramatically. Grinspun (1993) presents evidence of what has happened. One of the major factors was the shift in the exchange rate. As he states, it was largely the "macroeconomic mishandling of the Canadian economy. The view that elimination of barriers to trade is enough to equalize productivity levels ... is simplistic and fails to consider a host of other important factors that affect productivity" (1993: 108). Though freer trade alone may not be fully culpable, it is evident that enhanced productivity — which may not even occur in those industries with a disproportionate share of women workers - maybe a double-edged sword. That is, despite greater productivity, a rise in wages (labor costs) could lead to worker displacement. Further, those unable to improve levels of productivity would likely be replaced by other means of production.

In a number of manufacturing subsectors, many with a high number of women employed, the percentage of job losses has been higher than 26 percent: textiles (32 percent) and apparel (33 percent). Other sectors of the economy have also experienced declines. Services, where most Canadians are employed, lost 591,000 jobs (8 percent) (Campbell, 1993: 100). Some firms have shifted to part-time or temporary employees, resulting in further erosion in benefits and job security. Statistics Canada (1994) reports that 26 percent of 
all women employed outside the home work part-time as compared to 9 percent of employed men; overall, 69 percent of all part-time workers in Canada are female (Statistics Canada, 1995). Further, more than a third of those females employed part-time "indicated that they wanted fulltime employment" (Statistics Canada, 1995: 9). In the apparel industry, work-primarily by immigrant and minority women - has shifted from factories to homes, which for the most part is an unregulated environment. The result is that already low earnings are reduced even further.

\section{Economic Restructuring in Canada}

In Ontario, provincial statistics indicate that 65 percent of manufacturing jobs lost (19891992) were due to permanent plant closings. The manufacturing sector in Canada now employs only about 15 percent of the total workforce, perhaps the lowest in the industrialized world (Campbell, 1993: 100). Some economists would view this as alarming, especially in a world of global competition where a nation's economic future may depend on industrial and technological innovation and output. Although a variety of reasons are given for the sharp decline in manufacturing jobs, the reality is that many lives were changed or disrupted in some way as a result of job losses. Even if only a portion is in some way the result of free trade, the losses are no less significant.

Although Canadian wages have been higher than those in the U.S., it is the wage differential between Canada and Mexico that presents a serious problem (Ryals, Sennott, and Huber, 1993). The addition of a third world country into the freer trade zone presents MNCs with an opportunity that is hard to resist. As NAFTA evolves, the potential exists for a significant amount of direct investment to shift from Canada to Mexico. This would translate into dramatic changes in the Canadian economy.

\section{Social Restructuring in Canada}

The impact of NAFTA on women may be more significant in some regions of Canada than in others. Historically, there have been regional economic differences in average income, type of employment, and unemployment rates. For many years the Central region, with a large industrial and population base, has had a higher average income and lower unemployment rate (Ensign, 1994). 
Women in the urban areas have had more opportunities, but they may also be quite vulnerable to changes in the economy. As a group, women may also be affected because they move in and out of the workforce more frequently (e.g., family leaves). They may find it is more difficult to locate employment or be the first to lose their jobs.

Women in rural areas may see their wages and/or family income changed under NAFTA. Canadian farm families have seen an erosion in income. Lower prices (despite increased exports) have resulted in a greater dependence on off-farm income. Less than half the family income is currently earned from farm product sales. The majority of farm women have been forced to seek extra work. If farm income declines further, rural communities will deteriorate further.

Perhaps most alarming is that NAFTA will bring pressure on national and provincial policies that may result in changes or elimination of some social benefits. It is already evident that the frequency of legal challenges to trade agreements will increase rather than abate. The safety net that has been so important to the Canadian people - especially to women and children - may be threatened. In Canada, 16.4 percent of all households are headed by single women; most are poor and rely on the federal government to provide assistance. ${ }^{3}$ Furthermore, a reduction in services would be particularly hard on women in rural areas. Recent economic problems have already resulted in federal cutbacks to provinces for health care. Under NAFTA, some medical facilities have been forced to privatize. Competition through privatization places the emphasis on profits rather than providing care. In the foreseeable future, less-profitable services could be eliminated or streamlined through reductions in both the quality and quantity of health care provided. This streamlining may be detrimental for all concerned, but particularly devastating for those seeking natal and prenatal care. In fact, the entire health maintenance system is at risk if it is challenged as an unfair barrier to trade. If freer trade is the absolute goal, the very sovereignty of Canada is at stake.

${ }^{3}$ In the United States, 20.8 percent of households are headed by single women (Alt-WID, 1993). 


\section{WOMEN AND NAFTA: MEXICO}

It is reasonable to expect that freer trade and investment will enhance the overall economic development of Mexico. As a country, Mexico will see some economic gains. During the past twenty years, Mexico has experienced economic growth resulting from the large inflow of foreign direct investment (primarily from the U.S.). NAFTA will accelerate this trend. It encourages the free movement of investment; it promises trade advantages. With an emphasis on low-cost production, firms will take advantage of third world wages in a freer trade zone. The wage rate in the maquiladoras has been even lower than that in other facilities. Although foreign firms are attracted by the low cost of labor, many insist that they have also been attracted by lower labor and environmental standards as well as less enforcement of such standards. On anticipated changes resultant of NAFTA, Orme (1993: 3) admitted that the "task requires some initial pain and disruption-mostly in Mexico."

\section{Fast Track Modernization in Mexico}

Because of declining foreign investment in the early 1980s, Mexican law was amended to permit 100 percent ownership of non-strategic sectors of industry. MNCs are likely to continue entering capital intensive industries employing few workers. Vickers (1991) reports that small and medium-sized Mexican firms are being rapidly displaced by competition from the MNCs. In all of this, women have been "cast as invisible actors in the social development drama" (Ruiz and Tiano, 1987: 1).

In the past, most of the foreign direct investment went to the production facilities along the U.S.-Mexico border. These maquiladoras are labor intensive operations reliant on cheap labor - a low minimum wage combined with piecework. Gereffi (1992) characterizes the maquiladoras as a predominantly foreign enclave separate from Mexico's industrial structure, where women - many under the age of 25-are a major part of the workforce. Terpstra and David (1991) report between 67 to 85 percent of assembly workers are women between the ages of 16 and 25. Common selection criteria for these women include: six to nine years of education, are childless, were recommended by another worker, and have no prior work experience (Terpstra and David, 1991). The result is a docile workforce with no preconceived ideas. "The employment of women in maquiladora 
companies conflicts in some ways with traditional Mexican social organization of gender roles" (Terpstra and David, 1991: 161). The women are more independent than previously, but the norms for behavior may separate them from both their families and communities. With a diminished chance of marriage, they are categorically viewed by Mexican males as prostitutes due to their shedding of the customary reliance on men. Ruiz and Tiano (1987: 5) corroborate the view that "women's industrial employment threatens to destroy the traditional Mexican family" and that "these newly independent women neglect their children and emasculate the men, who sometimes resort to alcohol and substance abuse as salve for their 'wounded machismo'." At the same time, male unemployment remains very high in the region (Terpstra and David, 1991). Gereffi (1992) notes a developing trend, a bifurcation in the maquiladora industry. The 'old-style' labor-intensive production, which combines minimum wages with piecework, hires mostly women. A 'second wave' of operations with substantial capital in technology is hiring a growing number of males. The proportion of males working in maquiladoras has risen from below 20 percent to about 35 percent and in some sectors it is even higher (Gereffi, 1992).

\section{Welfare Concerns in Mexico}

NAFTA has increased the number of production facilities patterned after these maquiladoras, and there is little doubt that women in Mexico have not been beneficiaries. Concern has been voiced that the Mexican government has not made significant progress to counteract poor safety and environmental conditions that exist in some workplaces. Health problems are already a great concern. Women are at risk that have worked and/or lived near

poor environmental conditions. Reproductive and child health problems are already being linked to these conditions. The National Toxics Campaign Fund reported "widespread and serious contamination by U.S.-owned firms operating along Mexico's border," calling the area a " 2,000 mile Love Canal” (O’Connor, 1991). The American Medical Association describes it as “a virtual cesspool and breeding ground for infectious disease ... Uncontrolled air and water pollution is rapidly deteriorating and seriously affecting the health and future economic vitality on both sides of the border." A major concern since the passage of NAFTA is that these conditions will continue or even worsen. 
Because some MNCs may follow the pattern established by the more recent maquiladoras - which included the hiring of more men - women may not receive improved wages or position. Women entering the labor pool are seen as merely supplementary wage earners which becomes a justification for paying lower wages and relegating them to temporary jobs without benefits (Jacobsen, 1994; Ruiz and Tiano, 1987). Masculinization of the labor force, if anything, creates a number of disparities between men and women. Kopinak (1993: 148) finds "this new segmentation of the maquiladora labour force has disadvantaged women workers." In electronics assembly, women are employed in the least skilled and automated jobs. In automobile-related manufacturing, women are often paid a lower wage than are men. Typically, they are managed with patriarchal ideologies.

\section{Mexican Labor}

Although it might seem logical that wages will increase as a result of NAFTA, there are a number of reasons why this is not likely to happen. A shortage of potential workers is unfathomable at this point. Unemployment is very high (estimates range from 20 to 70 percent). Approximately one million workers join the workforce each year and this is not likely to change in the future as 40 percent of the population in Mexico remains under the age of 15 . There is also pressure from the government and domestic workers to keep wage rates low. Organized labor in Mexico has been described as weak, non-confrontational, and cooperative with both employers and the government. Employees have been desensitized and trained not to react (Kootnikoff, 1992).

The Mexican industrial policy of el pacto, or national wage and price control, is largely concerned with increased productivity. Representatives of government, business, and labor have settled on a National Productivity Accord as well as a Pact on Stability, Competitiveness and Employment (Cohen, 1993). A further example of government influence occurred when President Carlos Salinas gave Volkswagen permission to abandon the union contract. Volkswagen promptly fired 14,000 workers and rehired all of them back under a new contract, minus the 300 dissidents (Business Week, 1993). ${ }^{4}$

\footnotetext{
${ }^{4}$ Wood (1993: 4) states that the "legislative and judicial branches of government are rubber stamps of the executive."
} 
Moreover, government can declare a strike political and then declare it nonexistent, forcing workers to give up the struggle or their job. As if holding down wages and keeping a tight grip on union activity were not enough, the maquiladoras also form associations to fix labor costs (wages, benefits, and conditions) to avoid costly bidding. In essence, with ineffective unions and a virtual absence of protective labor legislation, safety and wage standards are not costs that an MNC moving into or expanding in Mexico will incur (Dilts and Walker, 1993). In response, many are calling for a social tariff to put the playing field back in balance.

\section{Prospects for the Future of Women in Mexico}

For many years, women (as well as young girls) in rural areas have been forced to seek extra work in order to survive. Holt (1994: 178) reports that women have been "pushed into the unstable informal economy and stand a greater chance of being poor." The Mexican government has ignored regional dimensions of industrial conversion and has failed to address the distinctly separate rural and urban sectors (Holt, 1994). One major difference is that households headed by women are more numerous in cities (Brydon and Chant, 1989). Farms have not been productive and government price supports and credit have been reduced. Recent legislation to modernize agriculture (attract foreign agribusiness to increase productivity) will reduce small farm income further and increase poverty. ${ }^{5}$ Mexico is currently importing vast quantities of cheap corn from the United States and Canada. The result is a scenario in which individuals leave the countryside in droves (Orme, 1993; Vickers, 1991), adding to the labor supply. In turn, more downward pressure is exerted on wages (Faux and Lee, 1992; Koechlin and Larudee, 1992). This intimates a less than bright future for most women in Mexico.

\footnotetext{
${ }^{5}$ For an in-depth examination of the transition problems for Mexican agriculture due to NAFTA see Levy and van Wijnbergen (1995).
} 


\section{DISCUSSION}

The nature of world business has changed and so has the landscape, "from insular concerns with domestic enterprise to a growing recognition of the existence of a global economy" (Wood and Cochran, 1992: 2). Hirst and Thompson (1992: 359) record international interactions as analogous to a 'billiard ball' dynamic; "international events do not directly penetrate or permeate the domestic economy but are refracted through national policies and processes." Politicization of economic and social aspects of life, both intra-nationally and internationally is on the rise (Kobrin, 1982). Nevitte, Basanez, and Inglehart (1992: 245) believe that the "prospects for continental integration hinge on both economics and values." They allude to changes in prevailing economic cultures of the three nations and identify significant differences among and within the nations. They do however conclude that a cultural convergence will occur. Cultural harmonization may not be a desirable state. Culture can perhaps be envisioned as a hegemonic export. Thompson (1992) records that Canadians routinely use the term 'cultural imperialism' whereas sociologists prefer the euphemism 'cultural diffusion'. Gustavo del Castillo Vera (1992) warns of cultural domination and reminds those charged with the duty of handling commercial agreements that they must strive to maintain the varied cultures in existence. In keeping with Hirst and Thompson (1995), it is found that nation states - indeed trade blocs and other regimes - are of continued importance and that their influence is not diminishing, but that the significance of their roles in the new polity is being altered through their interactions which are both changing in kind and rising in frequency.

\section{In Search of a Lens With Which to See}

The multiplicity of disciplines on which to draw and approaches that are applicable or appropriate make for interesting analyses. Singling out one factor in globalization may prove to be a useful exercise. Technology for instance typifies the duality inherent in any meaningful discussion. Technology may be a tool as well as a weapon. It can be an instrument for development and prosperity as well as exploitation and control. Is the choice of terms (development/prosperity and exploitation/control) simply a reflection of different perspectives? Wood (1994) wrestles with the nature of whether the path of globalization is one of prosperity or inequality. Wood's (1994) treatise 
takes the hemisphere as the unit of analysis. Dividing the planet into North and South for the level of discussion makes for quite an interesting lens.

Preston, Rey, and Dierkes (1978) have pointed to increasing international interest in altering corporate-society relationships. Global stakeholders as well as multi-cultural social and political issues call for a breaking free of myopic analysis. But liberation is not easy; Bell (1978) views the economy, the polity, and culture as dictates of contrary axial principles. Different logics of cause and effect animate different paradigms in economics (Feiner, 1995: 1). Feiner elaborates that it is important to be aware of the presuppositions in competing interpretations. She records that it is "generally agreed that structural changes in the U.S. economy since the 1970s have had profound consequences for all," but that little consensus has been reached on the long-term effects of these changes on the "continued secondary position of women" (Feiner, 1995: 2). In order to gain insight and ultimately generate a solution requires that the problem (a conflicting array of interests) be identified, understood, and then formulated into a workable model. The problem is clearly one of complex and interdependent relationships. Insight is developed through conjointly decomposing the issues into various elementary factors while maintaining a holistic view. That is, one must break down the issues into respective components while simultaneously maintaining a perspective of synthesis. Sklar (1980: 555) records that the "parameters of political discourse and policy have been tightened" and that this results in not merely the staking out of a position, to which all must conform or privately oppose, but "seeks to determine and limit the entire spectrum of thought."

Bearing in mind the rapidity and thrust of these social changes helps clarify the reasons why economic research has not kept pace with all the critical issues now brought to the fore.... The focus of the field on human beings dictates an approach that supports the application of economic tools in ways that enlighten understanding of behavior patterns, rather than abstracting from them in some mechanical way. Although human beings embody labor power, both as acting and reacting agents, they are more than an impersonal form of capital. Interpretation of behavior according to theoretical principles may make a tidier package, but not necessarily a more meaningful one.... To evaluate properly what is 
happening, we must give greater visibility to analyses critical of the existing order and of the way the order impinges on roles and personality traits of workers.... Moreover, there is need for an expanded application of research techniques, wedding policy implementation with evaluation. (Kahne with Kohen, 1975: 1275-1276)

Jacobsen (1994) gives account of the tendency for the analyst to hold the model dearer than the phenomenon in question. She points to how quickly rich and multiple stories are scorned, despite the fact that it is the anecdotes that provide most of the analyst's factual beliefs. Methodologically, economists rely heavily on statistics to the exclusion of case studies (Jacobsen, 1994). Likewise, Vernon (1994b) finds economists slow to take up the challenge of explaining the strategies of MNCs, and expresses 'substantial doubts' that models, particularly those that attempt to portray oligopolistic conditions, can open up the nature of MNC behavior. On a similar vein, Preston (1975: 441) takes to task those who see "a world composed of abstract aggregates." He foretells of a future in which conceivably the constructs of the corporation and society are merged into a single state. If the view of society and the firm were synonymous across disciplines, insights would be acute. According to Preston (1975), those credited with the generation of a model capable of portraying the interaction of society, state, and firm would become Nobel Laureates or recipients of the John Bates Clark Medal. "Sociologists observesome with excitement, others with trepidation - that economists are attending more to sociological concerns, even winning Nobel prizes for doing so" (Baron and Hannan, 1994: 1111). Baron and Hannan (1994) observe that it is only recently that economists have become interested in the internal workings of organizations. This is indeed the case, Stiglitz (1991: 15) admits, that economists have left the "study of organizations to business schools, or worse still, to sociologists." Frey and Eichenberger (1993) observe that research by American economists tends to focus on abstract issues whereas the activities of European economists tend to be concerned with practical issues.

Preston and Post (1975) call for the delineation between the management and society relationship and the business and government relationship. They argue that the participation of managerial interests in the political process is critical and that it need be "overt and clearly identified, not clandestine or 
camouflaged.... Such participation is inevitable and legitimate; and, as public policy becomes an increasingly important consideration in the process of management, such participation can be expected to become more widespread and significant" (Preston and Post 1975: 147). Kinnock (1994: 125) finds awesome both the "scale and scope of the linkages which today bind the economic fate of the world together." Kinnock's (1994: 124) solution to the attainment of "desirable conditions of liberty, prosperity, security, and stability" is quite simple, "there has to be an ethical basis for economic endeavor." "However, increased economic activity increases opportunities to profit from unethical behavior, eroding ethical standards over the long run" (Noe and Robello, 1994: 531). Weber (1995) finds that the ethical climate has bearing on organizational decision making. On the subject of what shapes MNC behavior, Buckley (1993) concurs that management decision making plays a vital role in determining the scope, direction of growth, and opportunities for the firm.

Determining the nature and extent of MNC activity as well as the consequences of specific behaviors is a curiosity that Waldman (1973) would like satisfied. He makes the point that legal norms and codes must be part of such analysis. Boddewyn and Brewer (1994: 119) recognize the "role of government as a factor of production, which firms must manage in their international value chain." They depict business political behavior as both a dependent and independent variable that must be taken into account in research, especially in those studies dealing with international issues.

\section{CONCLUSION}

Negotiators that drew up NAFTA were careful to specify economic issues-such as intellectual property laws important to MNCs — but virtually ignored human rights and human welfare issues. ${ }^{6}$ A humane government

\footnotetext{
${ }^{6}$ ) In an interview, Ambassador Katz, Deputy US Trade Representative, responded: "issues of immigration and labor, or the admission of Mexican labor to the United States, is not considered to be a subject of the free trade negotiations.... When we get into broad scale immigration, you're not dealing with trade or even wholly economic issues, you're dealing with social issues. And there's a whole panoply of other policies involved, and we've agreed that Will not be a part of this negotiation" [emphasis added] (Rogacki, 1991: 39).
} 
should correct major imbalances and assist those adversely affected in the national interest (Hansen, 1992; Ross, 1976). Part of Ruiz and Tiano's (1987) solution involves concerted policies to counteract the tendency of modernization to marginalize women. Heenan (1993: 8) similarly concludes that "Washington should be more generous in extending retraining and relocation assistance to those Americans adversely affected by NAFTA's open borders." Nobel laureate Robert Solow (1994: 5) bluntly, "there is something wrong with a society that punishes some people and rewards others just because they have personal characteristics for which they are not responsible and cannot control." Solow (1994: 8) states that government intervention may be required but cautions that "there is a lot of experience to suggest that direct intervention, attempts to change behavior by command, work badly, even perversely." His solution- "to operate through the market, by changing the previous rules of the game" (Solow, 1994: 8).

Recent discussions related to human rights and the renewal of China's most-favorednation trade status suggest that the U.S. could have brought more pressure to the negotiating table with Mexico. But ignoring thorny problems seemed to satisfy the three heads of state who were strong-arming a deal that was certain to please big business interests, especially MNCs in the U.S. and Canada. The concerns voiced are clearly not a development that is either recent or unique to NAFTA. Root and Mennis (1976: 17) conclude that the MNC is "disrupting in the United States and other industrial countries the traditional relations between business, government and unions that have been largely confined in the past to a single national domain. These traditional relations are now in disequilibrium: the multinational domain of the MNC is not matched by governments and unions." Graham and Krugman (1995: 88) further document this view of the MNC as one in which the MNCs are seen as "possessing political power disproportionate to that of domestic interest groups." Gladwin and Walter (1976: 57) find that $\mathrm{MNC}$ activity in one country is "frequently exposed to scrutiny and comment of governments or interest-groups in others" and that MNC social responsiveness must contend with both policy independence and interdependence. Epstein (1987) finds that reliance on the American legal system alone will be insufficient for expressing 
key societal values and establishing standards of business performance. Epstein urges attention to relationships and interactions which encompass a wide array of "internal and external, domestic and international stakeholders" (1987: 106).

Could the three North American states come up with a progressive mechanism for integration? Less than optimistically, Orme (1993: 2) summarized NAFTA debate as involving "competing domestic political agendas and irreconcilable world views." The European Community which did not have a less developed country as a member, still managed to establish a Regional Development Fund to finance economic development in the areas that need the greatest assistance. The European Community created a humane doctrine, the Social Charter, which ensures rights for its citizenry and instills responsibilities for government and the MNC. Finally, to ensure successful implementation, a sequence of initiatives was put in place. Eden and Molot (1993b: 231) have signaled for a revamping of Canadian national policy to include "human capital development through national education, retraining and adjustment assistance policies." More than 100 heads of state attended the World Summit for Social Development held in Copenhagen in 1995. It was expressed that macroeconomic and social policies must be mutually supportive "to create stable conditions to stimulate enterprise and job creation, to promote the proper functioning in the labor market, to assist employers and workers in adapting to change and to guarantee adequate social protection for all” (Work in America, 1995: 5).

In a pre-NAFTA article, Ambassador John D. Negroponte (1991: 7) called for "new forms of cooperation, understanding and interdependence." In that article, he states that "we have long thought that fair trade, based on common rules, favors global economic development and political freedom" and that there is "no reason to fear honest competition." Based on the premise of equality he foretells of "the potential of using free trade as a means of vaulting a Third World country right into the First World" (Negroponte, 1991: 7). Jagdish Bhagwati heeds us to "refuse to get into close embrace of the integration variety with nations that do not accept, and promise to work towards, a narrowly defined, common set of standards of a decent society." While not prescriptive, this admonition is timely and provides a directive for setting the course for globalization. By following this advice and through a conscious effort, Canada, Mexico, and the United States should be able to 
secure upward harmonization.

Now that NAFTA has come to fruition, it should be possible to focus attention on the impact that the North American Free Trade Agreement will have on women and to take definite action. Action should be directed at trying to: first prevent negative consequences from occurring; second reduce the negative impact (quantity and quality) of those that will occur; third ensure the equitable distribution of benefits; and last, as a reactive measure, to follow up on those to whom benefits did not accrue and to those upon which hardship fell.

Acknowledgements: Earlier versions of this essay were presented at the International Conference on Economic Integration and Public Policy, York University and the Annual Women's Studies Conference, Kent State University. I thank participants for their comments. I am grateful for suggestions provided by Rafael Montoya-Ortega, Iris Tiemessen, and Asbjorn Osland. Support as a Fulbright Scholar from the Foundation for Educational Exchange between Canada and the United States, the Institute of International Education, and the J. M. Smucker Company is gratefully acknowledged.

\section{REFERENCES}

Alternative Women-In-Development. (1993) Breaking boundaries: Women, free trade and economic integration. Washington, DC: Center of Concern.

Alternative Women-In-Development. (1995) Women's lives in a changing world. Washington, DC: Center of Concern.

Banner, D.K. (1979) Business and society: Canadian issues. Toronto, Ontario: McGraw-Hill.

Baron, J.N. \& Hannah, M.T. (1994) The impact of economics on contemporary sociology. Journal of Economic Literature. 32(3), 1111-1146.

Bednarzik, R. A. (1993, February) An analysis of US industries sensitive to foreign trade, 19821987. Monthly Labor Review, 15-31.

Bell, D. (1978) The cultural contradictions of capitalism. New York, NY: Basic Books.

Bhagwati, J. Multilateral and regional trade negotiations: The odd couple. Unpublished manuscript: Columbia University.

Blau, F.D. \& Kahn, L.M. (1992) The gender earnings gap: Learning from international comparisons. American Economic Review. 82(2), 533-538.

Boddewyn, J.J. (1988) Political aspects of MNE theory. Journal of International Business Studies. 19(3), 341-363.

Boddewyn, J.J. \& Brewer, T.L. (1994) International-business political behavior: New theoretical directions. Academy of Management Review. 19(1), 119-143. 
Brydon, L. \& Chant, S. (1989) Women in the third world: Gender issues in rural and urban areas. Aldershot, England: Edward Elgar.

Buckley, P.J. (1993) The role of management in internalisation theory. Management International Review. 33(3), 197-207.

Business Week. (1993, April) The Mexican worker. 19: 84-92.

Campbell, B. (1993) Restructuring the economy: Canada into the free trade era. In R. Grinspun \& M.A. Cameron (Eds.), The political economy of North American free trade (pp. 89104). New York, NY: St. Martin's Press.

Canada. (1992) North American free trade agreement: An overview and description-Canada, Mexico, United States. Ottawa, Ontario: Government of Canada.

Canada. (1993) NAFTA: What's it all about? Ottawa, Ontario: External Affairs and International Trade Canada.

Clarkson, M.B.E. (1988) Corporate social performance in Canada, 1976-86. In L.E. Preston (Ed.), Research in corporate social performance and policy (pp. 241-2 65). London, UK: JAI Press.

Cohen, J.A. (1993, June) Productivity: A jump start to better wages. Business Mexico. 7-8.

Cohen, M.G. (1987) Free trade and the future of women's work: Manufacturing and service industries. Ottawa, Ontario: Canadian Centre for Policy Alternatives.

Congressional Budget Office. (1993) Displaced workers: Trends in the 1980s and implications for the future. Washington, DC.

del Castillo Vera, G. (1992) The cultural dimension of a free trade agreement: The case of Mexico. In S.J. Randall, H. Konrad, \& S. Silverman (Eds.), North America without borders? Integrating Canada, the United States, and Mexico (pp. 261-268). Calgary, Alberta: University of Calgary Press.

Dilts, D.A. \& Walker, W.H. Jr. (1993, July) Labor standards and North American free trade: Economic dynamics or dilemmas? Labor Law Journal. 445-448.

Eden, L. \& Molot, M.A. (1993a) Insiders and outsiders: Defining "who is us" in the North American automobile industry. Transnational Corporations. 2(3), 31-64.

Eden, L. \& Molot, M.A. (1993b) Canada's national policies: Reflections on 125 years. Canadian Public Policy. 19(3), 232-251.

Ensign, P.C. (1994) The resurgence of regionalism: An examination of Canada. Proceedings of the International Trade and Finance Association (pp. 523-535). University of Reading, England.

Epstein, E.M. (1987) The corporate social policy process: Beyond business ethics, corporate social responsibility, and corporate social responsiveness. California Management Review. 29(3), 99-114.

Faux, J. (1993, July-August) The NAFTA illusion. Challenge. 4-8.

Faux, J. \& Lee, T. (1992) The effect of George Bush's NAFTA on American workers: Ladder up or ladder down? Washington, DC: Economic Policy Institute.

Feiner, S.F. (1994) Race and gender in the American economy: Views from across the spectrum. Englewood Cliffs, NJ: Prentice Hall. 
Frey, B.S. \& Eichenberger, R. (1993) American and European economics and economists. Journal of Economic Perspectives. 7(4), 185-193.

Friedman, M. (1962) Capitalism and freedom: A leading economist's view of the proper role of competitive capitalism. Chicago, IL: University of Chicago Press.

Friedman, M. (1970, September) Social responsibility of business. The New York Times Magazine. 13: 32, 33, 122, 124, 126.

Friedman, M. (1972) An economist's protest: Columns in political economy. Glen Ridge, NJ: Thomas Horton.

Friedman, S. (1992, September-October) NAFTA as social dumping. Challenge. 27-32.

Gereffi, G. (1992) Mexico's maquiladora industries and North American integration. In S.J. Randall, H. Konrad, \& S. Silverman (Eds.), North America without borders? Integrating Canada, the United States, and Mexico (pp. 135-151). Calgary, Alberta: University of Calgary Press.

Gilman, C.P. (1898) Women and economics: A study of the economic relation of men and women as a factor in social revolution. Boston, MA: Small Maynard.

Gladwin, T.N. \& Waiter, I. (1976) Multinational enterprise, social responsiveness, and pollution control. Journal of International Business Studies. 7(2), 57-74.

Graham, E.M. \& Krugman, P.R. (1995) Foreign direct investment in the United States (3rd ed.). Washington, DC: Institute for International Economics.

Grinspun, R. (1993) The economics of free trade in Canada. In R. Grinspun \& M.A. Cameron (Eds.), The political economy of North American free trade (105-124). New York, NY: St. Martin's Press.

Hansen, N. (1992) Regional employment implications of a free trade agreement. Labor Law Journal. August: 518-529.

Heenan, D.A. (1993) After NAFTA: The long-term benefits. Journal of Business Strategy. 14(3), 5-8.

Herremans, I.M., Ryans, J.K. \& Ran, P. (1994) Canadian business perspective on NAFTA. International Trade Journal. 8(1), 117-144.

Hirst, P. \& Thompson, G. (1992) The problem of 'globalization': International economic relations, national economic management and the formation of trading blocs. Economy \& Society. 21(4), 357-396.

Hirst, P. \& Thompson, G. (1995) Globalization and the future of the nation state. Economy \& Society. 24(3), 408-442.

Holt, R.P.F. (1994) The 1982 reforms and the employment conditions of Mexican women. In N. Aslanbeigui, S. Pressman, \& G. Summerfield (Eds.), Women in the age of economic transformation: Gender impact of reforms in post-socialist and developing countries (pp. 178-191). London, England: Routledge.

Jacobsen, J.P. (1994) The economics of gender. Cambridge, MA: Blackwell.

Jasay, A.E. (1960) The social choice between home and overseas investment. Economic Journal. $70,105-113$.

Joekes, S.P. (1987) Women in the world economy: A United Nations International Research and Training Institute for the Advancement of Women study. New York: Oxford University Press. 
Johnson, H.G. (1970) The efficiency and welfare implications of the international corporation. In C.P. Kindleberger (Ed.), The international corporation (pp. 35- 56). Cambridge, MA: MIT Press.

Kahne, H. with Kohen, A.I. (1975) Economic perspectives on the roles of women in the American economy. Journal of Economic Literature. 14(4), 1249-1292.

Kinnock, N. (1994) Beyond free trade to fair trade. California Management Review. 36(4), 124135.

Kobrin, S.J. (1975) Foreign direct investment, industrialization and social change: Acculturation and modernization in developing countries. Ph.D. dissertation, University of Michigan.

Kobrin, S.J. (1976) Foreign direct investment, industrialization, and social change. Journal of Conflict Resolution. 20(3), 497-522.

Kobrin, S.J. (1982) Managing political risk assessment: Strategic response to environmental change. Berkeley, CA: University of California Press.

Koechlin, T. \& Larudee, M. (1992, September-October) The high cost of NAFTA. Challenge. 19-26.

Kootnikoff, L. (1992, June) Survival of a labor leader. Business Mexico. 34-35.

Kopinak, K. (1993) The maquiladorization of the Mexican economy. In R. Grinspun \& M.A. Cameron (Eds.), The political economy of North American free trade (pp. 141- 162). New York, NY: St. Martin's Press.

Krugman, P. (1993) The uncomfortable truth about NAFTA: It's policy, stupid. Foreign Affairs. 72(5), 13-19.

Lee, T.M. (1993) The likely impact of NAFTA on women and minorities: Testimony before the Employment, Housing and Aviation Subcommittee of the US House of Representatives Committee on Government Operations, November 10. Washington, DC: Economic Policy Institute.

Leftwich, R.H. \& Sharp, A.M. (1980) Economics of social issues (4th ed.). Dallas, TX: Business Publications.

Levy, S. \& van Wijnbergen, S. (1995) Transition problems in economic reform: Agriculture in the North American Free Trade Agreement. American Economic Review. 85(4), 738-754.

Loprest, P.J. (1992) Gender differences in wage growth and job mobility. American Economic Review. 82(2), 526-532.

Macmillan, K. (1988) Women and free trade, (Trade Monitor No. 5). Toronto, Ontario: C. D. Howe Institute.

Negroponte, J.D. (1991) Continuity and change in US-Mexican relations. Columbia Journal of World Business. 26(2), 7-10.

Nevitte, N., Basanez, M., \& Inglehart, R. (1992) Directions of value change in North America. In S.J. Randall, H. Konrad, \& S. Silverman (Eds.). North America without borders? Integrating Canada, the United States, and Mexico (pp. 245-259). Calgary, Alberta: University of Calgary Press.

Noe, T.H. \& Rebello, M.J. (1994) The dynamics of business ethics and economic activity. American Economic Review. 84(3), 531-547.

O’Connor, J. (1991) Executive Director. National Toxics Campaign Fund, press conference, Washington, DC. February 12. 
Ohmae, K. (1995) The end of the nation state: The rise of regional economies. New York: Free Press.

Orme, W.A. Jr. (1993) Myths versus facts: The whole truth about the half-truths. Foreign Affairs. 72(5), 2-12.

Porter, M.E. (1991) Canada at the crossroads, the reality of a new environment. Ottawa, Canada: Business Council on National Issues, Industry, Science and Technology Canada, Department of International Trade.

Preston, L.E. (1975) Corporation and society: The search for a paradigm. Journal of Economic Literature. 13(2), 434-453.

Preston, L.E. \& Post, J.E. (1975) Private management and public policy: The principle of public responsibility. Englewood Cliffs, NJ: Prentice-Hall.

Preston, L.E., Rey, F. \& Dierkes, M. (1978) Comparing corporate social performance: Germany, France, Canada, and the US. California Management Review. 20(4), 40-49.

Rogacki, C. (1991) An interview with Ambassador Julius Katz. Columbia Journal of World Business. 26(2), 39-41.

Root, F.R. \& Mennis, B. (1976) How multinational corporations, unions, and government view each other and the direction of US policies. Journal of International Business Studies. 7(1), 17-30.

Ross, H.L. (1976) Poverty: Women and children last. In J.R. Chapman (Ed.). Economic independence for women: The foundation for equal rights (pp. 137-154). London, England: Sage Publications.

Rugman, A.M. (1987) Investment from the US: The logic in our favour. CA Magazine. May: 4652.

Ruiz, V.L. \& Tiano, S. (1987) Women on the US-Mexico border: Responses to change. Boston, MA: Allen \& Unwin.

Ryals, R.A., Sennott, F.J., \& Huber, T.J. (1993) Preparing for NAFTA: Social security and employee benefits in Mexico, Canada, and the USA. Benefits \& Compensation International. June: 16-24.

Sethi, S.P. (1995) Introduction to AMR's special topic forum on shifting paradigms: societal expectations and corporate performance. Academy of Management Review. 20(1), 18-21.

Short, D., Highfill, J.K., \& Weber, W.V. (1994) Workforce gender and net exports in US manufacturing industries. Proceedings of the International Trade and Finance Association (pp. 511-521). University of Reading, England.

Sklair, L. (1991) Sociology of the global system. New York, NY: Harvester Wheatsheaf.

Sklar, H. (1980) Trilateralism and the management of contradictions: Concluding perspectives. In H. Sklar (Ed.), Trilateralism: The trilateral commission and elite planning for worm management (pp. 555-585). Montreal, Quebec: Black Rose Books.

Smith, A. (177611976]) The wealth of nations. Chicago, IL: University of Chicago Press.

Solow, R. (1994) How race and gender issues arise in economics. In S.F. Feiner (Ed.). Race and gender in the American economy: Views from across the spectrum (pp. 5-8). Englewood Cliffs, NJ: Prentice Hall.

Statistics Canada. (1994) Women in the labour force. Ottawa, Ontario. 
Statistics Canada. (1995) Women in Canada: A statistical report (3rd ed.). Ottawa, Ontario.

Stiglitz, J.E. (1991) Symposium on organizations and economics. Journal of Economic Perspectives. 5(2), 15-24.

Terpstra, V. \& David, K. (1991) The cultural environment of international business (3rd ed.). Cincinnati, OH: South Western.

Thompson, J.H. (1992) Canada's quest for cultural sovereignty: Protection, promotion, and popular culture. In S.J. Randall, H. Konrad, \& S. Silverman (Eds.), North America without borders? Integrating Canada, the United States, and Mexico (pp. 269-284). Calgary, Alberta: University of Calgary Press.

US International Trade Commission. (1991) The likely impact on the United States of a free trade agreement with Mexico. USITC Publication 2353. Washington, DC.

Vernon, R. (1971) Sovereignty at Bay: The multinational spread of US enterprises. New York, NY: Basic Books.

Safarian, A.Z. (1994a) Multinational enterprise and public policy: A study of the industrial countries. Journal of Economic Literature. 32(3), 1245-1247.

Vernon, R. (1994b) The economist's role in research on transnational corporations: Or why the dogs have barked so softly. Transnational Corporations. 3(3), 81-89.

Vickers, J. (1991) Women and the world economic crisis. London, England: Zed Books.

Waldman, J.M. (1973) Corruption and the multinational enterprise. Journal of International Business Studies. 4(1), 93-96.

Weber, J. (1995) Influences upon organizational ethical subclimates: A multi-departmental analysis of a single firm. Organization Science, 6(5), 509-523.

Wood, A. (1994) North-South trade, employment, and inequality. London, England: Oxford University Press.

Wood, C. (1993) Mexico: Respect restored. Economist. February 13: 2, 4, 6-8.

Wood, D.J. \& Cochran, P.L. (1992) Business and society in transition. Business \& Society. 31(1), 1-7.

Work in America Institute. (1995) Global employment. Work in America. 20(7), 5-7. 